\title{
PRINCIPLES OF INDEPENDENT ANARCHISTIC ETHICS IN THE DOCTRINE OF PETER KROPOTKIN
}

\section{Katarzyna Duda}

Kropotkin's philosophy is a creative modification of such ethical programs as individualism, nihilism, social Darwinism and naturalistic utilitarianism. His ethics convictions are completely free from religious assumptions. He suggested mutual help and cooperation for survival, because without solidarity of an individual and his species, animal world would neither develop, nor improve. Struggle for survival as defined by Kropotkin is the need for inner-species alliance, cooperation for survival. In this context, fight for survival should be understood as fight through cooperation, cooperation becomes a weapon.

Keywords: ethics, mutual aid, egalitarism, utopianism

We will begin the discussion on the ethic programme of Kropotkin with the quotations of Tadeusz Kotarbiński, the creator of derivate notion of independent ethics that matches ethics programme formulated by Kropotkin. The quoted fragments contain basic assumptions of the Russian ideologist of communist anarchism concerning the origin of moral feelings and their fundamental principle: "Model of decent human being did not descent from the nether world nor is it an echo of permanent ideal existing in the dimensions of pure ideas" 1 - wrote the Polish philosopher. "Until now, material needs and external conditions of existence have determined what was happening to people in the greater extent than their so-called spiritual needs and finally, voice of conscience, being in the scope of our interests, was developed in accordance with this historic environment full of dithers and fights between people, as well as against nature, for survival. This is the genesis of moral feelings ac-

\footnotetext{
KATARZYNA DUDA, mgr, doktorantka, Uniwersytet Opolski, Polska; adres do korespondencji: ul. Zatorze 22/4, 48-130 Kietrz, Polska; e-mail: katarzyna.duda1990@gmail.com

${ }^{1}$ T. Kotarbiński, Żyć zacnie, Nasza Księgarnia, Warszawa 1989, p. 81.
} 
cording to materialists rejecting the phantasm of its supernatural origin" . He recommends to: "Proceed in such a way so as to encourage, develop and solidify, in the society we shape, motivation typical for the attitude of positive protectiveness"3.

\section{Principles of anarchistic independent ethics}

Kropotkin ethics convictions are completely free from religious assumptions. This anarchist, in his considerations, expressed conviction that moral sense has telluric origin and sufficient justification. Raising the issue of moral feelings, he argued that they have been inculcated in people by nature and exist due to their usability: Deeds perceived as morally good are those beneficial to the species, deeds perceived as evil are those that are harmful to the species. "The notion of good and evil is thus related neither to religion, nor to a mysterious conscience, it is a natural instinct of animal world" .

In the opinion of this thinker, "the whole animal world, including insects as well as human beings, knows what is good and what is evil and does not need bible or philosophy"5. He used empirical methods of natural sciences in order to find the common core of deeds widely regarded as good ${ }^{6}$. This belief placed him in naturalistic narration trend of thinkers perceiving nature holistically as an organic whole, consisting of identical building material, subject to identical processes and laws. Kropotkin argued: "Since man is a part of nature [...] there exists no reason to change our testing method while switching our study object from flower to human being, from beaver lodges to a human city"7. Drawing axiology from nature supposed to constitute a counterbalance to the theories that draw moral rules from supernatural sources.

Kropotkin ethics is independent also because it does not re-evaluate moral principles and ideas deemed natural. He would probably agree with Bakunin that: "We are absolute slaves of natural rights. But it is not humiliating and it is not slavery. Because there is no slavery without a master, principal external to the one he controls. Human being has

\footnotetext{
${ }^{2}$ Ibid., p. 42.

${ }^{3}$ Ibid., p. 38.

${ }^{4}$ P. Kropotkin, Pomoc wzajemna jako czynnik rozwoju, Oficyna Wydawnicza Bractwa "Trojka", Poznań 2006, p. 193.

${ }^{5}$ Ibid., p. 192.

${ }^{6}$ W. Rydzewski, Kropotkin, Wiedza Powszechna, Warszawa 1979, p. 56.

${ }^{7}$ Ibid., p. 93.
} 
only one freedom in relation to natural rights: acknowledge them and use them with growing effectiveness for various purposes, for emancipation and collective as well as individual humanisation"s.

Kropotkin's philosophy constitutes a polemic with various ethical programs, their creative modification. References to individualism, nihilism, social Darwinism and naturalistic utilitarianism in the anarchist's writings are numerous. Kropotkin took part in the most important scientific dispute of the turn of the 19th and the 20th century concerning the theory of evolution. He accused Herbert Spencer with misrepresentation and simplification of Darwin's science. Narrowing down the notion of fighting for survival - by limiting it to intra-species combat - social Darwinist ignored the issue of dominant factor of physical and mental development of mankind that is mutual assistance in facing unfavourable circumstances. Social habits provide defence against other species, facilitate food, enable longer life, facilitate development of mental capabilities. Struggle for survival as defined by Kropotkin is the need for inner-species alliance, cooperation for survival. In this context, fight for survival should be understood as fight through cooperation, cooperation becomes a weapon. "Without solidarity of an individual and his species, animal world would neither develop, nor improve. The best developed creature on earth would still be this water floating crumb, barely noticeable by means of a microscope. Would even these entities exist have the first cells not created offensive-defensive alliance while fighting?"9 .

In his work The Conquest of Bread, Kropotkin suggested introducing absolutistic egalitarianism. His concept of the society of fair distribution assumes the principle: "from each and to each at will"10. According to Kropotkin, the fundamental ethics principle is: "treat others as you would like to be treated in similar circumstances". Humanity striving for equality and realising "to everyone according to his needs" principle is indicated by centuries of bridges, roads and public libraries construction: "Entering any public library in London or Berlin, you are not asked by the librarian about your services to the society, but given requested publications" 11 . Monthly price of public means of transportation tickets is identical for all, regardless of the number of completed rides: "One person wishes to ride one thousand kilometres, another one - five

\footnotetext{
${ }^{8}$ M. Bakunin, Bóg i państwo, Bractwo Trojka, Poznań 2012, p. 52.

${ }^{9}$ P. Kropotkin, Pomoc wzajemna jako czynnik rozwoju, op. cit., p. 197.

${ }^{10}$ D. Grinberg, Ruch anarchistyczny w Europie Zachodniej 1870-1914, Wydawnictwo Naukowe PWN, Warszawa 1994, p. 118.

${ }^{11}$ P. Kropotkin, Zdobycie chleba, Nakładem księgarni J. Czerneckiego, Warszawa 1925 , p. 30
} 
hundred: these are strictly personal needs and there is no reason to make the first person pay twice as much as the second person due to the greater intensity of his or her need" ${ }^{\prime 2}$. Kropotkin justified his postulates with the fact that products resulting from the work of past generations and the result of effort of the whole present society are common heritage - the common good. Rejecting the individualistic rule of distribution of work effects and dualistic division into individual and collective work, he noticed that everything is a collective fact, born of past and present.

Kropotkin argued for a total cancellation of individual remuneration for work - harmfully subjective system, a tool in the hands of capitalists that serves covering exploitation that is hijacking collective work effects by an individual. He deemed that measuring the value of work contribution or the value of different professions is not objective ${ }^{13}$. Theories of salary scale were invented post factum for the purpose of excusing injustice. According to Kropotkin, along with elimination of paid work, goods evaluation system should be abolished. Work evaluation on the basis of manufacturing time and products evaluation on the basis of time of their production is unjustified, it is just reformed, softened individualism. Only collective consumption is appropriate for collective production. Sometimes Kropotkin supported making access to goods dependable on whether a person works several hours a day (from 4-5), however, it seems that in the end he aimed at separating the needs of individuals from their merits, evaluating needs as more important than past or future achievements of a human being for the society.

In ancient times, "man was fiercely fighting for poor existence with the cruel nature" 14 . The history of mankind is the history of conquering and managing nature, leading to the increase in material achievements, accumulation of benefits from culture and science ${ }^{15}$. Millions of human beings worked to create our civilisation that today makes our lives easier. "Generations of people that were born and died in poverty - wrote Kropotkin - exploited and kicked around by their masters, falling down under the burden of work, left us huge heritage [...]. Each machine has a similar history: a number of sleepless nights, fighting poverty, disappointments and raptures, partial improvements, performed by several generations of unnamed employees. Each new invention is the result of thousand other inventions" ${ }^{\prime \prime}$. Profit generated as a result of collective

\footnotetext{
${ }^{12}$ Ibid., p. 35.

${ }^{13}$ W. Rydzewski, Kropotkin, op. cit., p. 100.

${ }^{14}$ P. Kropotkin, Zdobycie chleba, op. cit., pp. 1-40.

${ }^{15}$ W. Rydzewski, Kropotkin, op. cit., p. 135.

${ }^{16}$ P. Kropotkin, Zdobycie chleba, op. cit., pp. 1-20.
} 
efforts - possible due to the tools created in the past - is unlawfully taken by a capitalist $t^{17}$. A handful of people usurp the right to the achievements of our ancestors.

Kropotkin supplemented his justification of absolute socialisation by raising the issue of interdependency and lack of self-sufficiency of individuals. He suggested looking at production from general, synthetic point of view, looking at mutual support of all spheres of the company's operations - "everything interweaves and crosses with each other, each production branch uses other, progress in one field results in progress in other fields"18. Time when "peasant family could consider grain they sowed and collected for the product of their own work" has passed ${ }^{19}$; today we can exist only in thousandth relationships, at the same time it is impossible to assess the value of any activity or function not being subject to favouring own profession. Anarchism was impatient, despised socialist struggle towards establishing eight-hour work day, perceiving them as petty. In the document La Revolte, it was written: "Eight working hours for an owner is eight hours too many. We know that our society is evil not because a worker works ten, twelve or fourteen hours, but because the owner exists" ${ }^{20}$. Their outlooks on work remuneration were similar. Insufficient earnings were not a problem. The problem was the idea of earning money itself.

\section{Accusations}

Primary objections towards the recommendations of Kropotkin include accusations of utopianism, naive optimism and messianism. Włodzimierz Rydzewski noticed that the formulated ideal is treated instrumentally by Kropotkin ${ }^{21}$. In the programme created for the Czajkowski group - "Should we consider the ideal of the future political system?", the anarchist agrees: "Although courage of thoughts by no means constitutes guarantee of courage in practical life, cowardice of thoughts is certainly a measure of cowardice in cases of practical realisation of thoughts" 22 . In the opinion of Kropotkin, effective theoretical criticism

\footnotetext{
${ }^{17}$ P. Laskowski, Szkice $z$ dziejów anarchizmu, Warszawskie Wydawnictwo Literackie Muza SA, Warszawa 2006, p. 146.

${ }^{18}$ P. Kropotkin, Zdobycie chleb, op. cit., p. 34.

${ }^{19}$ Ibid.

${ }^{20}$ B. Tuchman, Wyniosła wieża, Czytelnik, Warszawa 1987, p. 96.

${ }^{21}$ W. Rydzewski, Kropotkin, op. cit., p. 75.

${ }^{22}$ Ibid., p. 193.
} 
of a given political system is impossible, if there exists no concept of what is actually going to happen ${ }^{23}$. The accusation of Utopianism towards the proposed solutions can be rebutted with an argument that postulates proposed by Kropotkin were not absent in the world. He saw patterns of designed plans in local authorities or cooperatives based on the principle of group solidarism ${ }^{24}$, operating on the basis of medieval guilds.

Kropotkin was accused many times of naive faith in goodness of human beings. Kropotkin himself was "almost saintly; with thick beard and nice facial expression he could be taken for a shepherd from the Adorable Mountains. His only weakness was predicting war within the next fourteen days" ${ }^{25}$. English journalist, Henry Nevinson, who knew Kropotkin, claimed that this anarchist made an impression as if "he wanted to press the whole humanity against his heart and warm it up" ${ }^{26}$. Kropotkin emanated kindness - "he is one of these people who, in favourable circumstances, could become creators of large scale-social movements. Kropotkin is one of the most honest and ingenuous people I have ever encountered. He always tells people the truth to their faces with all the gentleness and amenity of a good man, but without indulgence for shallow ambitions of a listener. This absolute straightforwardness is the most striking and the most likable feature of his character. You can rely on everything he says" - wrote Sergey StepnyakKrawczynski in "Underground Russia"27. Kropotkin confronted the accusation of idealising people: "I predict an accusation that in this book (Mutual Aid: A Factor of Revolution), I have presented both animals and people in too optimistic manner, critics may say that I put emphasis on social features, only dabbing antisocial or egoistic pursuits. It was, however, unavoidable. In recent years, I heard so many times about the merciless struggle for existence, where allegedly each separate animal is against all animals, each separate wild man against all other wild men or each civilised man against all other citizens, that it is necessary to present them, first of all, a number of facts concerning animal and human life in a different light" ${ }^{28}$. Włodzimierz Rydzewski notices that Kropotkin "Makes thus, in a way, as a counterweight to: affirmation of harsh

\footnotetext{
${ }^{23}$ M. Waldenberg, Prekursorzy Nowej Lewicy: Studia z myśli spotecznej XIX i XX wieku, Wydawnictwo Literackie, Kraków 1985, p. 86.

${ }^{24}$ W. Rydzewski, Kropotkin, op. cit., p. 50.

${ }^{25}$ B. Tuchman, Wyniosła wieża, op. cit., p. 97.

${ }^{26}$ Ibid., p. 96.

${ }^{27}$ P. Kropotkin, Pomoc wzajemna jako czynnik rozwoju, op. cit., book's back cover.

${ }^{28}$ M. Waldenberg, Prekursorzy Nowej Lewicy, op. cit., p. 113.
} 
competition, fighting within the species, and - being aware of bias and one-sidedness of his statements - apotheosis of mutual help, solidarity, a socialisation tendency" ${ }^{29}$. Kropotkin did not negate other tendencies, he refused to acknowledge them as a factor of development and progress. The anarchist demonstrated in his writings the ostensibility of the following antinomy: individual interest - public good, which enables alleviating accusations of Messianism or Prometheanism. According to Kropotkin, success and working for a community are tantamount to the prosperity of individuals.

\section{Conclusion}

As a summarising reflection, it is worth mentioning the words of Daniel Grinberg that we can doubt practicality or chances of implementing solutions proposed by Kropotkin, but we should not be afraid of them ${ }^{30}$. Kropotkin hoped, perhaps against all odds, that at some point humanity will understand the benefits from proposed solutions and people will devote themselves to working for common welfare. Kropotkin's focus on the necessity of fulfilling needs, solidarity or self-governance has deeply humanistic meaning.

\section{Bibliography}

Bakunin M., Bóg i państwo, Bractwo Trojka, Poznań 2012.

Grinberg D., Ruch anarchistyczny w Europie Zachodniej: 1870-1914, Wydawnictwo Naukowe PWN, Warszawa 1994.

Kotarbiński T., Żyć zacnie, Nasza Księgarnia, Warszawa 1989.

Kropotkin P., Zdobycie chleba, Nakładem księgarni J. Czerneckiego, Warszawa 1925.

Kropotkin P., Pomoc wzajemna jako czynnik rozwoju, Oficyna Wydawnicza Bractwa "Trojka", Poznań 2006.

Laskowski P., Szkice z dziejów anarchizmu, Warszawskie Wydawnictwo Literackie Muza SA, Warszawa 2006.

Rydzewski W., Kropotkin, Wiedza Powszechna, Warszawa 1979.

Tuchman B., Wyniosta wieża, Czytelnik, Warszawa 1987.

${ }^{29}$ W. Rydzewski, Kropotkin, op. cit., p. 95.

${ }^{30}$ D. Grinberg, Ruch anarchistyczny w Europie Zachodniej 1870-1914, op. cit., p. 62. 
Waldenberg M., Prekursorzy Nowej Lewicy: studia $z$ myśli spotecznej XIX i XX wieku, Wydawnictwo Literackie, Kraków 1985.

\section{Zusammenfassung}

\section{Grundsätze der anarchistischen unabhängigen Ethik im Gedanken von Peter Kropotkin}

Die Philosophie von Kropotkin bildet eine innovative Entwicklung ethischer Programme des Individualismus, Nihilismus, Sozialdarwinismus und naturalistischen Utilitarismus. Kropotkins Ethik ist von religiösen Voraussetzungen vollkommen frei. Kropotkin schlägt gegenseitige Hilfe und Zusammenarbeit zum Überleben vor, weil es ohne Solidarität des Individuums und der Gattung in der Tierwelt keinen Fortschritt und keine Verbesserungen gegeben hätte. Der Kampf ums Überleben ist laut Kropotkin ein Bedürfnis der Zusammenarbeit innerhalb der Arten, des Bündnisses zwecks Überlebens. In diesem Zusammenhang sollte der Kampf ums Überleben als ein Kampf durch Zusammenarbeit verstanden werden - die Zusammenarbeit wird zur Waffe.

Schlüsselworte: Ethik, gegenseitige Hilfe, Egalitarismus, Utopismus

\section{Streszczenie}

\section{Zasady anarchistycznej etyki niezależnej w myśli Piotra Kropotkina}

Filozofia Kropotkina to twórcze rozwinięcie etycznych programów indywidualizmu, nihilizmu, darwinizm społecznego i naturalistycznego utylitaryzmu. Etyka Kropotkina jest zupełnie wolna od religijnych założeń. Proponuje on pomoc wzajemną i współprace w celu przetrwania, ponieważ bez solidarności jednostki i gatunku w świecie zwierzęcym nie byłoby ani rozwoju ani ulepszeń. Walka o przetrwanie wedle Kropotkina jest potrzebą wewnątrzgatunkowej współpracy, sojuszu w celu przetrwania. W tym kontekście walka o byt powinna być rozumiana jako walka poprzez współpracę - współpraca staje się bronią.

Słowa kluczowe: etyka, wzajemna pomoc, egalitaryzm, utopizm

Information about Author:

KATARZYNA DUDA, M.A., doctoral student, Opole University, Poland; address for correspondence: ul. Zatorze 22/4, 48-130 Kietrz, Poland; e-mail: katarzyna.duda1990@gmail.com 